\title{
Duchowość a jakość życia osób dotkniętych chorobą nowotworową
}

\section{Spirituality and quality of life of people affected by cancer}

\author{
Tamara Walczak¹, Elżbieta Walczak², Wiesław Kowalewski ${ }^{3 凶}$ \\ ${ }^{1}$ Uniwersytet Gdański, Instytut Psychologii, ul. Jana Bażyńskiego 4, 80-309 Gdańsk \\ University of Gdańsk, Institute of Psychology \\ ${ }^{2}$ Państwowa Wyższa Szkoła Zawodowa w Koszalinie, Biblioteka, ul. Leśna 1, 75-582 Koszalin \\ State University of Applied Sciences in Koszalin, Library \\ ${ }^{3}$ Państwowa Wyższa Szkoła Zawodowa w Koszalinie, Zakład Pielęgniarstwa, ul. Leśna 1, 75-582 Koszalin \\ State University of Applied Sciences in Koszalin, Department of Nursing \\ $\triangle$ wieslaw.kowalewski@op.pl
}

\begin{abstract}
Introduction: The quality of life of patients suffering from cancer is the subject of a vast body of research in the fields of psychooncology and health psychology. Much less frequent is research on spirituality as an important factor in patients' satisfaction with life. Due to the high popularity of the topic but the low number of reports, this study attempted to analyse and quantify the relationship between spirituality and quality of life of cancer patients.

Materials and methods: 94 people were invited to the study, 44 of whom at the time of the study were suffering from various forms of cancer, with the remaining 50 people as a control group (healthy people). A questionnaire was used to evaluate their satisfaction in various aspects of life and determine their levels of spirituality.

Results: Cancer patients assessed their levels of satisfaction with their life, health and physical well-being lower than healthy people. Those affected by cancer obtained higher scores on their strength of faith and intensity of the religious attitude in
\end{abstract}

comparison to healthy people. The results showed that satisfaction with life for healthy people was conditioned by their sense of harmony and meaning of life. In those affected by cancer, the relationship between satisfaction and sense of harmony was stronger, and in addition, the results indicated the importance of ethical sensitivity in the assessment of their own satisfaction with life, which was not observed in the group of healthy people. Conclusions: The lower satisfaction with life in cancer patients likely resulted from the negative balance of profits and losses in the face of a severe illness and even the risk of death. The greater intensity observed in the dimensions of spirituality may have resulted from the fact that those suffering from chronic or incurable diseases had entrusted their lives to a higher being, in order to gain faith and hope for a further fight against the disease. The patients' systems of values had changed - satisfaction with life, beyond the sense of life harmony, began to be conditioned by the ethical sensitivity of the patient.

Keywords: quality of life; spirituality; psycho-oncology; cancer.

\begin{abstract}
ABSTRAKT
Wstęp: Badanie jakości życia pacjentów chorujących na nowotwory jest przedmiotem ogromnej liczby prowadzonych badań z dziedziny psychoonkologii i psychologii zdrowia. Rzadziej podejmowana tematyka duchowości wydaje się ważną sferą życia pacjentów, która może warunkować stopień zadowolenia z życia (jakość życia). Ze względu na dużą popularność tematyki, ale małą liczbę doniesień w zakresie relacji obu aspektów życia osób dotkniętych chorobą nowotworową, w niniejszym badaniu podjęto próbę analizy związku tych zmiennych.

Materiały i metody: Do badania zaproszono 94 osoby, z czego 44 w momencie badania chorowały na różne postaci nowotworu, a pozostałe 50 osób stanowiło grupę porównawczą (osoby zdrowe). Dokonano pomiaru zadowolenia z różnych aspektów życia, a także siły duchowości badanych osób, wykorzystując w tym celu metody kwestionariuszowe.

Wyniki: Wykazano, że osoby chore gorzej oceniają zadowolenie ze swojego dotychczasowego życia, zadowolenie ze swojego zdrowia oraz ze sfery fizycznej. W badaniu sfery duchowości
\end{abstract}

osoby chore uzyskały wyższe wyniki w skalach siły wiary oraz nasilenia postawy religijnej w porównaniu z osobami zdrowymi. Dowiedziono, że u osób zdrowych zadowolenie z życia jest uwarunkowane poczuciem harmonii życiowej i sensu życia. Natomiast u osób chorych związek zadowolenia z harmonią życiową jest silniejszy, a ponadto wyniki wskazały na znaczenie wrażliwości etycznej dla oceny własnego zadowolenia, czego nie zaobserwowano w grupie osób zdrowych.

Wnioski: Mniejsze zadowolenie z życia prawdopodobnie wynika z bilansu zysków i strat dokonywanego przez chorych w obliczu ciężkiej choroby, a nawet ryzyka śmierci. Większe nasilenie wymiarów duchowości może wynikać z faktu, że osoby chorujące przewlekle lub nieuleczalnie powierzają swoje życie istocie wyższej, aby zyskać wiarę i nadzieję na dalszą walkę z chorobą. Zmianie ulega system wartości pacjenta - zadowolenie z życia, poza poczuciem harmonii życiowej, zaczyna być uwarunkowane wrażliwością etyczną chorego.

Słowa kluczowe: jakość życia; duchowość; psychoonkologia; choroba nowotworowa. 


\section{WSTĘP}

Każdy człowiek odczuwa stan swojego zdrowia inaczej, mniej lub bardziej świadomie. Zazwyczaj, gdy zachowana jest równowaga i dobre funkcjonowanie organizmu, człowiek w niewielkim stopniu koncentruje się na ochronie i poprawie zdrowia. W codziennym życiu ludzie dążą do zaspokajania bieżących potrzeb niedostatku i wzrostu [1]. Dopiero wtedy, gdy niedostatek zdrowia zaczyna zagrażać normalnemu funkcjonowaniu, człowiek ukierunkowuje swoje myśli i działania na zachowania związane ze zdrowiem. Chorobie pacjenta towarzyszą różne reakcje psychiczne, które pozostają zależne od uwarunkowań zewnętrznych (np. wsparcia społecznego) i wewnętrznych (np. zasobów psychicznych). Wpływają one na intelektualną ocenę sytuacji, a także na stan emocjonalny chorego. Do uwarunkowań zewnętrznych zaliczyć można kontrolowanie objawów, które pozwala na opanowanie bólu oraz dobrą organizację opieki, służącą właściwemu zaspokojeniu potrzeb pacjenta. W przypadku uwarunkowań wewnętrznych bierze się pod uwagę: reakcje osoby na sytuację choroby, strukturę osobowości, stosunek chorego do kwestii śmiertelności i umierania, a także jego system wartości, kulturę, religię czy tradycję [2].

Sytuacja poważnej choroby jest odmienna, gdyż do momentu diagnozy pacjent przeważnie wiódł zwyczajne życie, był czynny zawodowo i społecznie, cieszył się tzw. pełnią życia. Moment diagnozy wywołuje różne, często całkowicie odmienne reakcje. Jedni podejmują decyzję o walce z chorobą (postawa sprzyjająca leczeniu), szukają wszelkich metod, aby sobie pomóc: stosują diety, rozpoczynają współpracę z terapeutą, podejmują leczenie farmakologiczne, dostosowują styl życia do nowej sytuacji, czytają literaturę powiązaną z chorobą czy też szukają głębszych kontaktów z istotą wyższą. Na drugim biegunie pozostają osoby, które charakteryzuje rozpacz, rezygnacja, żal i oczekiwanie na śmierć (postawa niekorzystna dla leczenia). Ta grupa pacjentów pozostaje bierna, nie wierzy w skuteczność proponowanych przez personel medyczny działań [1]. Poza tymi dwoma, intuicyjnie rozpoznawalnymi grupami pozostaje jeszcze grono chorych, którzy zaprzeczają chorobie, niejednokrotnie twierdząc wręcz, że zdrowieją [2]. Doświadczenie nie pozwala zapomnieć także o tych pacjentach, którzy wraz z momentem diagnozy rozpoczynają walkę z czasem, chcąc wykorzystać pozostały im czas na podróże, hobby, spędzanie czasu z rodziną i bliskimi przyjaciółmi.

\section{Jakość życia w psychoonkologii}

Jakość życia najczęściej łączy się z pojęciem i wewnętrznym poczuciem „dobrego życia”, które wiedzie człowiek. W literaturze amerykańskiej połowy XX w. termin ten wiązano przede wszystkim z ilością posiadanych dóbr materialnych. Stopniowo włączano w opis tego pojęcia podmiotowość człowieka i takie kryteria, jak: edukacja, wolność, zdrowie, szczęście. Współcześnie definicja odnosi się do subiektywnego poczucia satysfakcji jednostek, a także do poczucia satysfakcji grup społecznych. Co więcej, oznacza postrzeganie przez jednostkę możliwości osiągnięcia przez nią rozwoju indywidualnego i społecznego [3]. W coraz większym stopniu problematyka jakości życia zaczęła interesować specjalistów z dziedzin medycznych, czego skutkiem stało się wypracowanie pojęcia jakości życia uwarunkowanej stanem zdrowia (health-related quality of life - HRQL), którą definiuje się jako funkcjonalny efekt choroby i jej leczenia odbierany przez pacjenta [4]. Ocena HRQL obejmuje: ocenę ogólną, obszar fizyczny, psychiczny i społeczny. De Walden-Gałuszko [4, 5] zaznacza, że wysoka HRQL w obszarze fizycznym oznacza brak dolegliwości i dobrą sprawność ruchową, w obszarze psychicznym brak objawów psychopatologicznych, natomiast w obszarze społecznym wiąże się z zachowaniem aktywności społecznej i zawodowej. Ocena jakości życia to nic innego jak obraz własnego położenia życiowego w pewnym okresie, przy czym owe położenie ma charakter relacyjny. Relacyjność oznacza porównanie z pewnym punktem odniesienia, standardem złożonym z własnych doświadczeń, wyobrażeń, życzeń czy sytuacją innych osób. Wyłaniają się zatem dwa ważne aspekty oceny jakości życia - położenie (sytuacja określona obiektywnie) i ocena danego zjawiska, z którą związane są określone przeżycia i poglądy oceniającego (mające charakter subiektywny) [3].

W psychologii pozytywnej osiąganie dobrej jakości życia związane jest z rozwijaniem sprawności - cnót, które powodują przyrost tzw. sił psychicznych. Siła psychiczna warunkuje zdolność do radzenia sobie w skuteczny sposób z wyzwaniami i trudnościami, jakie człowiek napotyka w życiu. Cnota jest definiowana jako spójność układu myśli, uczuć, motywacji i działania. Dzięki cnotom człowiek może skutecznie działać w życiu i społeczeństwie (w sposób spójny i zintegrowany), czerpiąc korzyści dla siebie i przyczyniając się do powstawania korzystnych warunków dla rozwoju innych ludzi. Przy okazji problematyki sił psychicznych należy odnieść się do popularnego ostatnio pojęcia „sprężystości psychicznej”, którą de Walden-Gałuszko [4] określa jako: „zdolność do przywracania sobie równowagi i efektywnego działania po przebytej traumie". Owa sprężystość wyraża się w pewnej elastyczności zastosowania schematów poznawczych do trudnych sytuacji, jakie jednostka napotyka w swoim życiu, a także do pozytywnej rekonstrukcji poczucia własnego ja i miejsca w świecie po przebytej traumie. Integrację i powrót do życia jednostce umożliwia reorganizacja życia i schematów, które zmienione po chorobie mogą stanowić wartość w postaci „nowej jakości”. Dobre rokowania w powrocie do równowagi psychicznej mają pacjenci o wysokich zdolnościach do samokontroli, czyli umiejętności kierowania swoim zachowaniem i regulowania stanów emocjonalnych, co wyraża się w odpowiedniej dystrybucji energetycznej mającej na celu rozbudzenie korzystnej aktywności i hamowania tej niewłaściwej (nieadaptacyjnej). Ta niepożądana aktywność jest hamowana u pacjentów poprzez m.in. wyciszenie, ćwiczenia oddechowe, odwracanie uwagi od bólu (świadome kierowanie procesami uwagi) czy przeczekanie nieprzyjemnych (destrukcyjnych) myśli. De Walden-Gałuszko [4] podaje, że korzystna aktywność przyczynia się do rozwijania wspomnianych cnót na zasadzie sprzężenia zwrotnego - cnoty pomnażają siły psychiczne, które w następstwie umożliwiają ich praktykowanie.

Duchowość - jedna z cnót, o których wspomniano wyraża się w dążeniu do rozwijania i poszanowania obszaru 
duchowości, jaki tkwi w człowieku. Konceptualizuje się ją jako wiarę w istnienie Absolutu, Mocy, Natury, Boga oraz potrzebę dążenia do wartości niematerialnych takich jak: dobro, piękno i prawda. U znacznej części osób wiąże się z religijnością, czyli poszukiwaniem kontaktu z istotą wyższą. Taka potrzeba nabierać może dużego znaczenia zwłaszcza w chorobie, gdy wiara i religijność pomagają chorym przejść przez okres choroby, leczenia, a czasem i umierania [4, 6]. Rozwijanie cnót może korzystnie wpłynąć na jakość życia pacjenta. Dzięki nim nie tylko chorzy lepiej radzą sobie z sytuacją choroby i leczenia ale także ich życie nabiera nowej wartości - „jest bogatsze i pełniejsze niż przed chorobą" [4].

\section{Duchowość osób chorujących na nowotwory}

Duchowość uznawana jest przez psychologię zdrowia za atrybut człowieka, jednak przy braku założeń co do istnienia zjawisk nadprzyrodzonych, z których owa duchowość wypływa. Uznawana jest za konstrukt, na który składa się wiele wymiarów o charakterze teoretycznym, regulujących pewne obszary aktywności jednostki. Badania empiryczne dowodzą, że duchowość wiąże się z szansą na dłuższe życie, a także stanowi czynnik ochronny w przypadku zachorowań na wiele schorzeń somatycznych [7].

Tradycyjnie za istotę duchowości uznaje się zdolność do transcendencji, czyli przekraczania własnego „Ja realnego", co ma charakter rozwojowy - wzrostowy. Kierunek wykraczania poza „Ja” wyznaczają wartości odnoszące się do sfery niematerialnej, jakimi kieruje się osoba. Zatem o transcendencji można mówić zarówno w aspekcie samorealizacji, samodoskonalenia i samorozwoju, jak i wykraczania poza rozwój osobowy: dążenia do relacji z istotą wyższą czy wszechświatem. Kierunek może wyznaczać również inna osoba, której dobro staje się dla człowieka priorytetem [7]. Duchowy obszar człowieka, czyli jego wewnętrzna przestrzeń, zawiera oceny poznawczo-wartościujące, ale również potrzeby, czyli pragnienia oraz wartości niematerialne (np. prawdy, dobra). Poprzez odwoływanie duchowości do pojęć, a także zasad życia, jest ona bardzo często utożsamiana z poszukiwaniem sensu życia. Z punktu widzenia praktyk religijnych duchowość jest pojęciem, które oznacza sposoby, poprzez które osoba wierząca wyraża własną wiarę. W znaczeniu szerszym duchowość może być rozumiana jako przeżywanie wartości o charakterze pozamaterialnym. To doświadczenie decyduje o wewnętrznych rozterkach człowieka. Stąd też opieka duchowa udzielana chorym i umierającym jest zorientowana na poszukiwanie znaczenia i sensu ludzkiego życia, a także na odniesienie do zagadnień religijnych [2].

Chociaż specyfika duchowości wyraża się w możliwości jej rozwoju w ciągu całego życia człowieka, to są jednak pewne momenty, w których szczególnie się nasila. Heszen i Sęk [7] podają, że to właśnie poważna choroba somatyczna (przede wszystkim zagrażająca ludzkiemu życiu) jest wydarzeniem, które sprzyja przyrostom duchowości. Niezwykle ważne jest uwzględnienie w pracy terapeutycznej z pacjentem potrzeb religijnych. Osoba duchowna może wspomóc chorego w nawiązaniu osobistego kontaktu z Bogiem poprzez swoją obecność, rozmowę czy sakrament święty. Obecność duchownego powoduje, że pacjent bardzo często otwiera się, ale też chętniej słucha rad, czuje obecność drugiej osoby (towarzysza) w swoich duchowych przeżyciach. Doświadczenie specjalistów pokazuje, że właśnie w takich kryzysowych momentach w życiu ludzie szczególnie odnoszą się do wiary w Boga, a w momencie nadchodzącej śmierci chcą być utwierdzani w wierze w życie wieczne. Kapelani hospicyjni, którzy niosą pomoc choremu, ofiarując mu obecność wiary, ukazują sens cierpienia, a także jego głębszy wymiar. Taka pomoc duchowa służy uspokojeniu i wsparciu, które jest możliwe dzięki dobrej i życzliwej opiece oraz pracy terapeutycznej [2].

Relacja z osobami poważnie chorymi oparta na rozmowie dotyczącej ich potrzeb duchowych jest bardzo trudna nawet dla specjalisty z dużym doświadczeniem. Bardzo często pacjent odrzuca niesioną pomoc, nie przyjmuje zaproszenia do rozmowy, unika kontaktów, separuje się i oddala od terapeuty/duchownego, gdy ten porusza tematykę odnoszącą się do sfery duchowej. Doświadczone osoby pomagające czy opieka hospicyjna wiedzą doskonale, że takie zachowanie nie oznacza, iż osoba nie odczuwa potrzeby wsparcia duchowego. Postawa pacjenta jest niezwykle ważna - wyraża sprzeciw wobec postępującej choroby i śmierci, a także stanowi sygnał wołania o pomoc $[2,8]$.

Celem badania było pogłębienie wiedzy o duchowości i jakości życia pacjentów chorujących na chorobę nowotworową, a także poszukiwanie związków pomiędzy wymiarami tych dwóch konstruktów (duchowości i jakości życia). W badaniu postawiono zatem następujące pytania badawcze (P) i odpowiadające im hipotezy $(\mathrm{H})$ wypływające z przesłanek teoretycznych i dokonanego przeglądu badań:

P1: Czy istnieje różnica w poziomie zadowolenia pomiędzy grupą osób chorujących na nowotwory a grupą osób zdrowych? H1: Założono, że osoby zdrowe charakteryzują się wyższym poziomem zadowolenia niż osoby chore $w$ takich aspektach, jak: zadowolenie z dotychczasowego życia, zadowolenie z obecnej sytuacji, zadowolenie ze zdrowia, zadowolenie ze sfer: fizycznej, psychologicznej, społecznej i środowiskowej niż osoby chore. P2: Czy istnieje różnica w zakresie poziomu sensu życia, siły wiary, postawy religijnej, harmonii i wrażliwości etycznej pomiędzy grupą osób zdrowych a grupą osób chorujących na nowotwory?

H2: Założono, że osoby chore charakteryzują się wyższym poziomem sensu życia, siły wiary, postawy religijnej, harmonii i wrażliwości etycznej niż osoby zdrowe.

P3: Czy istnieje związek pomiędzy różnymi aspektami zadowolenia z życia (jakością życia) a poszczególnymi wymiarami duchowości?

H3: Założono, że w grupie osób chorych istnieje silniejszy związek pomiędzy poszczególnymi aspektami jakości życia a wyróżnionymi wskaźnikami duchowości.

\section{MATERIAtY I METODY}

\section{Osoby badane}

W badaniu wzięły udział 94 osoby, z czego 44 w momencie badania chorowały na różne postaci nowotworu, a 50 było zdrowych. Średni wiek w badanej próbie wyniósł M = 48,57, 
$\mathrm{SD}=14,32$. Przeciętny wiek $\mathrm{w}$ grupie chorych, w którym zdiagnozowano nowotwór, wyniósł $\mathrm{M}=49,80, \mathrm{SD}=9,64$. Wśród uczestników większość stanowili mężczyźni ( $\mathrm{n}=53)$. Najwięcej osób miało wykształcenie wyższe $(39,40 \%)$ i średnie (29,80\%). Najczęściej deklarowanym stanem cywilnym w badanej grupie był związek sformalizowany (mężatka/żonaty) - 43\%. Z kolei najmniejszy odsetek badanych to osoby będące w separacji - 1,10\%. Większość uczestników badania prowadziła gospodarstwo domowe z małżonkiem (46,80\%). Co trzeci badany zadeklarował, że żyje samotnie, a jedynie co dziesiąty mieszka ze swoim dzieckiem/dziećmi. Połowa uczestników deklarowała zamieszkiwanie dużego miasta, a 13\% to mieszkańcy wsi. Ponad połowa osób w momencie badania była aktywna zawodowo.

\section{Zmienne i narzędzia badawcze}

Analizie poddano następujące zmienne przy wykorzystaniu odpowiednio dopasowanych kwestionariuszy:

1. Jakość życia: Kwestionariusz World Health Organization Quality Of Life - WHOQOL-Bref (WHO, 1995; polska adaptacja: Wołowicka i Jaracz, 2001) - narzędzie przeznaczone do oceny jakości życia osób zdrowych i chorych w zakresie aspektów: fizycznego, psychologicznego, relacji społecznych oraz wpływów środowiska.

2. Zadowolenie z życia: Kwestionariusz SWLS - The Satisfaction with Life Scale (Diener, Emmons, Larsen i Griffin, 1985; polska adaptacja: Juczyński, 2001).

3. Sens życia: Skala Poczucia Sensu Życia PIL (Crumbaugh, Maholic, 1964; polska adaptacja: Płużek, 1994). Wysokie wyniki wskazują na zaspokojenie potrzeby sensu życia, niskie mogą świadczyć o frustracji egzystencjalnej.

4. Duchowość: Kwestionariusz samoopisu (Heszen-Niejodek, Gruszczyńska, 2004). Narzędzie posiada trzy podskale: skalę postaw religijnych (wykorzystywania praktyk religijnych w życiu codziennym), skalę wrażliwości etycznej (nasilenie postawy etycznej) oraz skalę harmonii życiowej (poczucie przynależności do świata, wewnętrznego spokoju, radości, poczucia, że w świecie jest wiele miłości i postrzegania świata jako przyjaznego).

5. Siła przekonań religijnych: Skala Siły Wiary Religijnej Santa Clara (the Santa Clara Strength of Religious Faith Questionnaire - SCSORF) służąca do oceny przekonań religijnych niezależnych od prezentowanego przez badanych wyznania religijnego.

\section{Procedura}

Badania prowadzone były w koszalińskich placówkach pomocy osobom chorym na nowotwory (fundacje, stowarzyszenia) i miejskim szpitalu. Osoby zdrowe rekrutowano spośród studentów sopockiego wydziału Uniwersytetu SWPS. Uczestnicy podpisali zgodę na udział oraz zostali poinformowani o dobrowolności udziału i możliwości wycofania zgody na każdym etapie prowadzonego badania. Po uzupełnieniu kwestionariuszy zainteresowane osoby były informowane o celu i szczegółach badania.

\section{WYNIKI}

Analizy danych dokonano, wykorzystując pakiet IBM SPSS for Windows. Przeprowadzono testy t-Studenta dla grup niezależnych oraz analizy korelacji Pearsona.

Pierwsze pytanie badawcze dotyczyło różnic w zakresie zadowolenia ze swojego życia między osobami chorymi a zdrowymi. W hipotezie założono, że zadowolenie to będzie wyższe u osób zdrowych w porównaniu z chorującymi na nowotwory. Wyniki przedstawiono w tabeli 1.

We wszystkich analizowanych aspektach poziom zadowolenia jest większy u osób zdrowych w porównaniu z osobami chorymi. Różnice istotne statystycznie zaobserwowano jedynie w przypadku 3 analizowanych zmiennych: zadowolenia z dotychczasowego życia (osoby zdrowe: $\mathrm{M}=3,88, \mathrm{SD}=0,63$; osoby chore: $\mathrm{M}=3,37, \mathrm{SD}=0,73$ ), zadowolenia ze swojego zdrowia (osoby zdrowe: $\mathrm{M}=3,50, \mathrm{SD}=1,02$; osoby chore: $\mathrm{M}=2,80$, $\mathrm{SD}=0,90$ ) oraz zadowolenia ze sfery fizycznej (osoby zdrowe: $\mathrm{M}=4,35, \mathrm{SD}=1,17$; osoby chore: $\mathrm{M}=3,70, \mathrm{SD}=1,35$ ). Zatem częściowo potwierdziła się hipoteza pierwsza zakładająca większe zadowolenie z życia osób zdrowych w porównaniu z osobami chorującymi na nowotwory.

Drugie pytanie badawcze dotyczyło występowania różnic w sferze duchowości reprezentowanej przez takie zmienne, jak: poczucie sensu życia, siła wiary, postawa religijna, harmonia i wrażliwość etyczna między osobami zdrowymi a osobami chorymi. W hipotezie założono, że chorzy będą charakteryzowali się wyższymi wynikami na wszystkich wymiarach duchowości w porównaniu z osobami zdrowymi. Jak pokazano w tabeli 2, występują istotne statystycznie różnice w sile wiary (osoby zdrowe: $\mathrm{M}=28,54, \mathrm{SD}=12,59$; osoby chore: $\mathrm{M}=38,34$,

TABELA 1. Zadowolenie z różnych aspektów swojego życia w zależności od stanu zdrowia

\begin{tabular}{|c|c|c|c|c|c|c|}
\hline \multirow{2}{*}{ Parametry } & \multirow{2}{*}{$\begin{array}{c}\text { Test } \\
\text { t-Studenta }\end{array}$} & \multirow{2}{*}{$\mathbf{p}$} & \multicolumn{2}{|c|}{ Osoby zdrowe } & \multicolumn{2}{|c|}{ Osoby chore } \\
\hline & & & M & SD & M & SD \\
\hline Zadowolenie z dotychczasowego życia & $-3,65$ & $<0,01$ & 3,88 & 0,63 & 3,37 & 0,73 \\
\hline Zadowolenie obecnie & 0,84 & $>0,05$ & 3,72 & 0,78 & 3,57 & 0,97 \\
\hline Zadowolenie ze zdrowia & $-3,53$ & $<0,01$ & 3,50 & 1,02 & 2,80 & 0,90 \\
\hline Zadowolenie ze sfery fizycznej & $-2,48$ & $<0,05$ & 4,35 & 1,17 & 3,70 & 1,35 \\
\hline Zadowolenie w sferze psychologicznej & $-1,61$ & $>0,05$ & 3,53 & 0,60 & 3,31 & 0,72 \\
\hline Zadowolenie w sferze społecznej & $-1,21$ & $>0,05$ & 3,82 & 0,81 & 3,61 & 0,90 \\
\hline Zadowolenie w sferze środowiskowej & $-1,33$ & $>0,05$ & 3,45 & 0,49 & 3,30 & 0,64 \\
\hline
\end{tabular}


$\mathrm{SD}=10,85$ ) oraz postawie religijnej (osoby zdrowe: $\mathrm{M}=21,28$, $\mathrm{SD}=7,11$; osoby chore: $\mathrm{M}=27,30, \mathrm{SD}=6,54$ ) między osobami chorymi a osobami zdrowymi. W przypadku pozostałych aspektów: sensu życia, harmonii i wrażliwości etycznej nie uzyskano różnic istotnych statystycznie.

Wykazano, że u osób chorych na nowotwór obserwuje się większą siłę wiary oraz silniejszą postawę religijną w porównaniu z osobami zdrowymi. W przypadku pozostałych aspektów duchowości: sensu życia, harmonii i wrażliwości etycznej nie uzyskano różnic istotnych statystycznie.

Ostatnie pytanie badawcze dotyczyło związku pomiędzy różnymi aspektami poczucia zadowolenia z życia a poszczególnymi wymiarami duchowości. W hipotezie założono, że związki te będą silniejsze między tymi dwoma konstruktami w grupie osób chorych w porównaniu z osobami zdrowymi. Wyniki zaprezentowano w tabelach 3 i 4 .

W grupie osób chorych występują istotne statystycznie, dodatnie korelacje na poziomie umiarkowanym między poszczególnymi aspektami zadowolenia z życia a harmonią $(r=0,45-0,71)$ i wrażliwością etyczną $(r=0,39-0,42)$, w mniejszym stopniu również poczuciem sensu życia $(\mathrm{r}=0,33-0,36)$. Z kolei w przypadku osób zdrowych występują istotne i dodatnie korelacje między poszczególnymi aspektami zadowolenia z życia a poczuciem harmonii $(r=0,32-0,61)$ i sensu życia $(r=0,28-0,58)$.

\section{DYSKUSJA}

Celem badania było pogłębienie wiedzy na temat różnych aspektów duchowości i jakości życia, a także poszukiwanie związków pomiędzy tymi dwoma konstruktami w przypadku osób nieuleczalnie/przewlekle chorych na przykładzie grupy ludzi chorujących na nowotwory.

Uzyskane wyniki wskazują, iż chorujący na nowotwory różnią się od osób zdrowych zadowoleniem ze swojego dotychczasowego życia, oceniając ten aspekt gorzej. Powyższy wynik można wyjaśnić poprzez odniesienie do bilansu zysków i strat często dokonywanego przez chorych. Doświadczenie ciężkiej choroby niesie za sobą brak pewności jutra, a niejednokrotnie perspektywę bliskiej śmierci. W związku z tym nie dziwi fakt, że u chorych może pojawiać się żal, że nie przeżyli inaczej swojego życia czy że nie spożytkowali lepiej czasu, jaki był im dany [9].

TABELA 2. Poczucie sensu życia, siła wiary, postawa religijna, harmonia i wrażliwość etyczna w zależności od stanu zdrowia

\begin{tabular}{|c|c|c|c|c|c|c|}
\hline \multirow{2}{*}{ Parametry } & \multirow{2}{*}{ Test t-Studenta } & \multirow{2}{*}{$p$} & \multicolumn{2}{|c|}{ Osoby zdrowe } & \multicolumn{2}{|c|}{ Osoby chore } \\
\hline & & & $M$ & SD & $M$ & SD \\
\hline Sens życia & $-1,05$ & $>0,05$ & 27,38 & 2,47 & 26,55 & 4,76 \\
\hline Siła wiary & 3,94 & $<0,01$ & 28,54 & 12,59 & 38,34 & 10,85 \\
\hline Postawa religijna & 4,25 & $<0,01$ & 21,28 & 7,11 & 27,30 & 6,54 \\
\hline Harmonia & 0,92 & $>0,05$ & 21,08 & 3,53 & 21,82 & 4,21 \\
\hline Wrażliwość etyczna & 1,24 & $>0,05$ & 26,87 & 3,89 & 27,95 & 4,65 \\
\hline
\end{tabular}

TABELA 3. Korelacje (r-Pearsona) między aspektami zadowolenia z życia i aspektami duchowości w grupie osób chorych na nowotwory

\begin{tabular}{|c|c|c|c|c|c|c|c|}
\hline Parametry & $\begin{array}{c}\text { Zadowolenie } \\
\text { z dotychczaso- } \\
\text { wego życia }\end{array}$ & $\begin{array}{l}\text { Zadowolenie } \\
\text { obecnie }\end{array}$ & $\begin{array}{c}\text { Zadowolenie } \\
\text { ze zdrowia }\end{array}$ & $\begin{array}{l}\text { Zadowolenie } \\
\text { ze sfery } \\
\text { fizycznej }\end{array}$ & $\begin{array}{l}\text { Zadowolenie } \\
\text { ze sfery } \\
\text { psychicznej }\end{array}$ & $\begin{array}{c}\text { Zadowolenie } \\
\text { ze sfery } \\
\text { społecznej }\end{array}$ & $\begin{array}{c}\text { Zadowolenie } \\
\text { ze sfery } \\
\text { środowiskowej }\end{array}$ \\
\hline Sens życia & $0,33^{*}$ & 0,21 & 0,18 & 0,26 & $0,36^{*}$ & $0,36^{*}$ & 0,17 \\
\hline Siła wiary & 0,01 & 0,01 & $-0,15$ & $-0,02$ & 0,02 & 0,04 & $-0,04$ \\
\hline Postawa religijna & 0,14 & 0,15 & $-0,01$ & 0,12 & 0,19 & 0,10 & 0,12 \\
\hline Harmonia & $0,67^{* *}$ & $0,50 * *$ & $0,47^{* *}$ & $0,60 * *$ & $0,71^{\star *}$ & $0,45^{* *}$ & $0,62^{* *}$ \\
\hline Wrażliwość etyczna & $0,39 * *$ & 0,24 & 0,25 & $0,40 * *$ & $0,39 * *$ & 0,24 & $0,42^{\star *}$ \\
\hline
\end{tabular}

* różnica istota statystycznie na poziomie $\alpha=0,05$; ** różnica istotna statystycznie na poziomie $\alpha=0,01$

TABELA 4. Korelacje (r-Pearsona) między aspektami zadowolenia z życia i aspektami duchowości w grupie osób zdrowych

\begin{tabular}{|c|c|c|c|c|c|c|c|}
\hline Parametry & $\begin{array}{c}\text { Zadowolenie } \\
\text { z dotychczaso- } \\
\text { wego życia }\end{array}$ & $\begin{array}{l}\text { Zadowolenie } \\
\text { obecnie }\end{array}$ & $\begin{array}{c}\text { Zadowolenie } \\
\text { ze zdrowia }\end{array}$ & $\begin{array}{c}\text { Zadowolenie } \\
\text { ze sfery } \\
\text { fizycznej }\end{array}$ & $\begin{array}{c}\text { Zadowolenie } \\
\text { ze sfery } \\
\text { psychicznej }\end{array}$ & $\begin{array}{c}\text { Zadowolenie } \\
\text { ze sfery } \\
\text { społecznej }\end{array}$ & $\begin{array}{c}\text { Zadowolenie } \\
\text { ze sfery } \\
\text { środowiskowej }\end{array}$ \\
\hline Siła wiary & $-0,05$ & $-0,17$ & $-0,13$ & $-0,20$ & $-0,16$ & $-0,24$ & $-0,18$ \\
\hline Postawa religijna & 0,10 & $-0,05$ & $-0,06$ & $-0,21$ & 0,01 & $-0,15$ & 0,06 \\
\hline Wrażliwość etyczna & 0,17 & 0,08 & 0,01 & $-0,05$ & 0,14 & $-0,08$ & 0,18 \\
\hline
\end{tabular}

* różnica istota statystycznie na poziomie $\alpha=0,05$; ** różnica istotna statystycznie na poziomie $\alpha=0,01$ 
Ponadto uzyskano wynik wskazujący na to, że chorzy są mniej zadowoleni niż zdrowi z własnego zdrowia oraz ze sfery fizycznej, co nie jest zaskakujące - choroba nowotworowa często wiąże się ze zmniejszeniem wydolności i kondycji fizycznej, a tym samym każdy wysiłek może być dużym obciążeniem dla organizmu [4]. Reorganizacja życia, skutki uboczne leczenia i powstałe ograniczenia powodują, że osoby chore często nie akceptują zmienionego wyglądu, a także zmniejszonych możliwości fizycznych. Niejednokrotnie nie potrafią zaakceptować i przyjąć oferowanej pomocy w wykonywaniu wielu czynności dnia codziennego i pozostają nieusatysfakcjonowane ze zmian w życiu seksualnym.

Wykazano, że osoby chorujące na nowotwór charakteryzuje wyższa siła wiary oraz bardziej nasilona postawa religijna w porównaniu z osobami zdrowymi. Uzyskany wynik jest zgodny z przesłankami teoretycznymi, które wskazują, że ludzie dotknięci bardzo trudnym doświadczeniem życiowym pokładają nadzieję w sile wyższej, co przynosi im ukojenie i łagodzi doznawane emocje [10].

Uzyskane wyniki wskazują ponadto, że w przypadku osób zdrowych zadowolenie z życia jest przede wszystkim uwarunkowane poczuciem harmonii i sensu życia. W przypadku osób chorych poczucie harmonii życiowej wydaje się jeszcze silniejszym czynnikiem warunkującym zadowolenie z życia. Zaskakujące może być jednak znaczenie nasilenia wrażliwości etycznej, która zdaje się warunkować zadowolenie z dotychczasowego życia, zadowolenie ze sfery fizycznej, psychicznej i środowiskowej chorego.

Wyniki mają charakter różnicowy, a więc nie wskazują na zależność przyczynowo-skutkową. Dlatego niniejsze badania mogą stanowić wstęp do dalszych analiz i próby weryfikacji czynników powodujących wzrost oceny jakości życia w różnych jego aspektach u osób przewlekle lub nieuleczalnie chorych. Ma to znaczenie m.in. ze względu na fakt, iż zachorowalność na raka ma tendencję wzrostową. W związku z tym liczba osób cierpiących na choroby nowotworowe i inne choroby cywilizacyjne będzie sukcesywnie wzrastać. Dlatego należy już teraz dołożyć starań w celu opracowywania coraz lepszych metod pracy z chorymi, aby pomóc im godnie przeżyć trudny okres i zoptymalizować jakość ich życia.

Duchowość obok jakości życia pacjenta stanowi ważne wyzwanie dla wielu ogniw personelu medycznego - w tym dla psychoonkologów - którzy koncentrując się na psychicznym funkcjonowaniu chorujących na nowotwory, przyczyniają się do poprawy zadowolenia z ich życia. Dzięki profesjonalnemu przygotowaniu psychoonkolog pracuje z pacjentem nad złagodzeniem bądź usunięciem negatywnych skutków psychicznych wywołanych stanem choroby bądź procesem leczenia. Jest to przeważnie praca z wachlarzem przykrych emocji odczuwanych przez pacjenta, takich jak lęk, gniew czy w końcu depresja. Terapeutyczna relacja jest szczególnie ważna w przypadku osób, które nie są w stanie same utrzymać równowagi psychicznej. Są to najczęściej pacjenci mający problem z przystosowaniem się do sytuacji choroby (16-42\% ogółu chorych na nowotwory wg de Walden-Gałuszko [4]). Duża część pacjentów radzi sobie jednak dobrze ze stresem chorobowym - odczuwają wsparcie bliskich, personelu medycznego czy też stosują wypracowane własne strategie obronne. Dla tych ludzi wartą uwagi propozycją jest psychologia pozytywna, która rozszerza i dodaje do terminu jakości życia aspekty pozytywne (w tym samorozwój) i podkreśla, że warunkiem szczęścia jest osiągnięcie pełnej dojrzałości psychicznej.

Człowiek z postępującą chorobą, doznaje niejednokrotnie coraz silniejszych dolegliwości fizycznych, do których dołącza się lęk oraz przygnębienie. Stan ten potęguje pojawiające się uczucie samotności (wewnętrznej - psychicznej), powodującej osamotnienie społeczne, w którym chory oddala się od bliskich. Izolacja jest bardzo często konsekwencją moralno-psychicznego cierpienia, które niejednokrotnie jest bardziej uciążliwe od bólu fizycznego i zazwyczaj pozostaje tajemnicą cierpiącego. Następstwem może być załamanie psychiczne, a często również depresja. Nie można w tym miejscu zapomnieć o coraz silniej odczuwanej samotności duchowej przez pacjenta. Jest to stan wywołany brakiem związku z istotą wyższą (Bogiem, Absolutem czy Wartością Najwyższą). Bywa, że ludzie wierzący mogą wytworzyć psychiczną barierę dzielącą człowieka i wspomnianą istotę wyższą. Rodzi to w osobie cierpiącej postawę buntu i niewiary. Na przeciwstawnym biegunie tych przeżyć znajduje się nadzieja, która wierzącym pomaga przygotować się na najgorsze - cierpienie czy też śmierć [2]. Nadzieja wykorzystywana w pracy terapeutycznej z pacjentem wywołuje jego optymizm, a także wpływa na lepsze przystosowanie do sytuacji choroby.

Nierzadko zdarza się, że choroba szybko postępuje - jak w przypadku niektórych nowotworów z przerzutami. Pacjent zmierzyć się musi wówczas z pojęciem śmierci bardziej niż kiedykolwiek. Kiedy jego siły słabną, jest w pełni zależny od leków przeciwbólowych i opieki medycznej, wówczas często załamuje się wskutek odczuwanej niemocy wobec cierpienia i swojej sytuacji, świadomości końca życia i nadchodzącej śmierci. Chory często odrzuca wtedy Boga, buntuje się przeciw niemu. Część osób odnajduje jednak w tej sytuacji pewną mądrość, dojrzałość, chęć poszukiwania kontaktu z istotą wyższą [2]. Dlatego tak ważne jest, aby nie zostawiać pacjentów samych sobie, aby nie kończyć swojej pomocy na podaniu leków i przeprowadzeniu kontrolnych badań. Dla chorego, który zmaga się ze świadomością śmierci, największymi potrzebami są te duchowe: obecności bliskich w przeżywaniu i poczucia obecności istoty wyższej. Ważna jest szczerość w relacji z nieuleczalnie chorym pacjentem (bądź takim, który jest u kresu życia), gdyż jej brak może przyczynić się do izolacji i niepokoju osoby w obliczu śmierci. Może to z kolei prowadzić do zmiany naturalnego procesu umierania w sztuczną sytuację, w której człowiek dodatkowo cierpi z powodu braku otwartości i szczerości.

W pracy z nieuleczalnie chorym pacjentem warto przyjmować filozoficzną perspektywę opisywaną przez Dyera [11], w której terapeutyczne okazuje się postrzeganie siebie jako duszy z ciałem niż ciała z duszą. Punkt ciężkości przesunięty jest wówczas z fizyczności, która jest powodem bólu i cierpienia pacjenta, na jego wnętrze, które może być źródłem twórczości i witalności. Być może kluczem do podtrzymania integralności psychicznej pacjenta jest włączenie w proces terapeutyczny również sfery jego duchowości. 


\section{WNIOSKI}

1. Osoby chorujące na nowotwory charakteryzuje niższa jakość życia (mniejsze zadowolenie z własnego życia) niż osoby zdrowe.

2. Osoby chore charakteryzuje większa duchowość niż osoby zdrowe w zakresie 2 aspektów - siły wiary i postawy religijnej.

3. U osób zdrowych zadowolenie z życia jest w umiarkowanym stopniu powiązane z poczuciem harmonii życiowej i poczuciem sensu życia. Natomiast u osób chorych zaobserwowano silniejszy związek z poczuciem harmonii życiowej, a także umiarkowany z wrażliwością etyczną.

4. W pracy terapeutycznej z pacjentem chorującym na nowotwór warto odnieść się do sfery jego duchowości, która często pełni funkcję zasobów i przyczyniać się może do wzrostu poczucia zadowolenia z życia (wyższej jakości życia).

\section{PIŚMIENNICTWO}

1. Jakubowska-Winecka A, Włodarczyk D. Psychologiczne aspekty choroby i chorowania. In: Jakubowska-Winecka A, Włodarczyk D, editors. Psychologia w praktyce medycznej. Warszawa: PZWL; 2007. p. 70-93.
2. Uchmanowicz E. Potrzeby duchowe i wsparcie psychologiczne ludzi będących u kresu życia w kontekście opieki hospicyjnej. Piel Zdr Publ 2012;1(2):67-72.

3. Kościelak R. Promocja zdrowia a jakość życia osób przewlekle chorych i niepełnosprawnych. In: Psychologia i medycyna. Wspólne obszary zainteresowań (praca zbiorowa). Warszawa: Vizja Press \& IT; 2007. p. 75-81.

4. De Walden-Gałuszko K. Psychoonkologia w praktyce klinicznej. Warszawa: PZWL; 2011.

5. De Walden-Gałuszko K. Jakość życia - rozważania ogólne. In: De Walden-Gałuszko K, Majkowicz M, editors. Jakość życia w chorobie nowotworowej. Gdańsk: Wyd. Uniw. Gdańskiego; 1994. p.13-38.

6. DeWalden-Gałuszko K. Problemy komunikacji. In: De Walden-Gałuszko K, editor. Psychoonkologia. Kraków: Biblioteka Psychiatrii Polskiej; 2000. p. 45-54.

7. Heszen I, Sęk H. Psychologia zdrowia. Warszawa: PWN; 2008.

8. Skuza B, Jakubowska-Winecka A. Psychologiczne problemy związane z terminalną fazą choroby. In: Jakubowska-Winecka A, Włodarczyk D, editors. Psychologia w praktyce medycznej. Warszawa: PZWL; 2007. p. 154-66.

9. Majkowicz M. Problemy i perspektywy oceny jakości życia w chorobie nowotworowej (ujęcie krytyczne). In: De Walden-Gałuszko K, editor. Psychoonkologia. Kraków: Biblioteka Psychiatrii Polskiej; 2000. p. 141-6.

10. Klatkiewicz A. Kryzys choroby czy szansa na zmianę swojego życia? Czynniki wpływające na postrzeganie i wykorzystanie sytuacji choroby jako możliwości zmiany swojego życia. In: Janowski K, Artymiak M, editors. Człowiek chory - aspekty biopsychospołeczne. Lublin: Wyd. Polihymnia; 2009. p. 485-94.

11. Dyer WW. Your erroneous zones. New York: Funk \& Wagnals; 1976. 
